\title{
Kadar Zat Besi (Fe) dan Daya Terima Flakes Talas (Colocasia esculenta (L.) Schott) dengan Substitusi Bayam (Amaranth sp.)
}

\author{
${ }^{1)}$ Aan Sofyan, ${ }^{2)}$ Naziela Eldiana Husna AZ \\ ${ }^{1,2}$ Program Ilmu Gizi FIK, Universitas Muhammadiyah Surakarta \\ email:aan.sofyan@ums.ac.id
}

\begin{abstract}
Flakes is a type of practical cereal food product that can be used for breakfast. Flakes product development is needed to improve physical, chemical and nutritional quality characteristics. Taro as a source of local food can be processed for basic ingredients of flakes. The combination of taro and spinach is expected to be an alternative diversification of flakes products that can be a source of $F e$ and can be accepted by panelists. The purpose of this study is to analyze the levels of Fe in taro flakes products with spinach substitution. The study was conducted by making variations of taro-based flakes with different percentages of spinach paste substitution, namely: SB1 (100: 0); SB2 (90:10); SB3 (80:20); SB4 (70:30). The results of the analysis of iron flakes content in a row are 20.56; 25.83; 30.77; and $34.25 \mathrm{mg} / \mathrm{kg}$, while the results of the acceptability analysis showed that flakes with spinach substitution of $0 \%(S B 1)$ was more acceptable both in the aspect of aroma, taste, texture, color, and overall.
\end{abstract}

Keyword: flakes, taro, spinach, iron, acceptability

\section{PENDAHULUAN}

Menurut Kasutic et al. (2016) flakes adalah makanan sereal harian yang biasa dijadikan menu sarapan pagi oleh sebagian masyarakat. Flakes bisa dijadikan menu makanan siap saji (ready to eat) yang memiliki banyak fungsi antara lain mempunyai peran dalam diet penyeimbang, sumber penting nutrisi untuk tubuh, dan juga bisa meningkatkan kecerdasan otak (Schwartz et al., 2008). Menurut Sukasih et al. (2012) pada saat ini sereal dapat dibuat dari bahan kombinasi umbi-umbian dengan sumber bahan pangan lain seperti kacang- kacangan untuk memperoleh produk sereal dengan gizi yang lengkap.

$$
\text { Talas (Colocasia esculenta }
$$

Scott.)adalah jenis umbi-umbianyang dapat dijumpai di seluruh dunia meliputi wilayah Asia, Afrika maupun Australia baik yang beriklim tropis maupun sub tropis (Chair, 2016). Varietas talas yang banyak tumbuh di Indonesia yaitu varietas $C$. esculenta var.esculenta yang memiliki ciri umbi berukuran besar dan panjang serta tidak bercabang (Prana, 2007). Menurut Prana (2007) jenis umbi talas tersebut yang umum diolah menjadi berbagai jenis makanan. 
Selain sebagai sumber karbohidrat, talas juga sebagai sumber protein, thiamin, riboflavin, besi, dan seng dan vitamin (Alcantara et al., 2013). Talas juga merupakan jenis tanaman pangan yang mempunyai sifat pangan fungsional (Sudomo et al., 2014). Senyawa bioaktif yang terdapat pada umbi talas dapat memberikan manfaat dalam menjaga kesehatan (Sudomo et al., 2014)

Tanaman bayam merupakan tanaman yang tahan terhadap kekeringan dan serangan penyakit serta mempunyai kandungan nutrisi yang sangat tinggi (Achigan-Dako, et al., 2014). Daun bayam kaya akan kandungan protein dan mikronutrien seperti besi, kalsium, seng vitamin $\mathrm{C}$ dan Vitamin $\mathrm{A}$ (Achigan-Dako et al., 2014). Menurut Srivastava (2011) kandungan mikronutrien pada bayam akan berbeda tergantung spesies dan cara budidaya. Kandungan Fe pada daun bayam liar lebih tinggi dibandingkan dengan bayam yang dibudidaya.

Zat besi (Fe) merupakan komponen penting bagi semua mahluk hidup baik manusia maupun hewan terutama untuk keberlangsungan proses metabolisme di dalam tubuh serta berperan vital dalam transport oksigen di dalam darah (Abbaspour et al., 2014 ). Rata-rata jumlah zat besi pada orang dewasa yaitu sekitar 4gr, dimana $50 \%$ dari total besi tersebut berada di hemoglobin dan beberapa sisanya ada yang tersimpan dalam hati (Abbaspour et al., 2014). Kekurangan zat besi dalam tubuh bisa menyebabkan malnutrisi yang berakibat pada terganggunya kesehatan (Abbaspour et al., 2014). Anemia merupakan kondisi dimana dalam tubuh tidak tersedia zat besi untuk melakukan sintesa hemoglobin sehingga tubuh menjadi lemah dan letih (Fitriany, 2018).

Pengembangan produk flakes dengan bahan dasar tepung ubi talas dan dengan substitusi pasta bayam diharapkan dapat menjadi produk sereal yang dapat dijadikan alternatif dalam pemenuhan nutrisi bagi masyarakat. Produk flakes dengan kandungan zat besi yang tinggi bisa dijadikan menu pilihan untuk mencegah terjadinya anemia. Menurut data yang dikeluarkan oleh Kemenkes RI (2014) negara Indonesia memiliki prevalensi yang tinggi terhadap kasus anemia sebesar 21,7\% (Kemenkes RI, 2014). Menurut Aminah (2016) bayam juga dapat dijadikan bahan fortifikan pada produk makanan untuk meningkatkan zat gizi agar status gizi meningkat. Penelitian ini bertujuan untuk mengetahui kadar zat Fe dalam flakes berbahan dasar umbi talas dengan kombinasi substitusi bayam. 


\section{METODE PENELITIAN}

Alat

Pada riset ini menggunakan beberapa alat yaitu antara lain: blender, neraca, loyang, rolling (flaking), oven listrik, grinder, ayakan 80 mesh, cabinet dryer, spektrofotometer serapan atom (SSA), lampu katoda beringga (Hallow Cathode Lamp), Erlenmeyer, dan pipet volume.

\section{Bahan}

Bahan yang digunakan yaitu: umbi talas, bayam hijau (Amaranthus hibrydus L), gula, garam, telur, susu skim, margarine, aquades, asam nitrat $\left(\mathrm{HNO}_{3}\right)$, gas etilen $\left(\mathrm{CH}_{2}\right)$, larutan kalsium $\left(\mathrm{CaCO}_{3}\right)$, asam klorida $(\mathrm{HCl})$

\section{Pembuatan Tepung Talas}

Pembuatan tepung talas mengacu pada penelitian yang dilakukan Paramita et al. (2015). Adapun proses pembuatan tepung talas seperti yang terlihat dalam diagram alir pada Gambar 1.

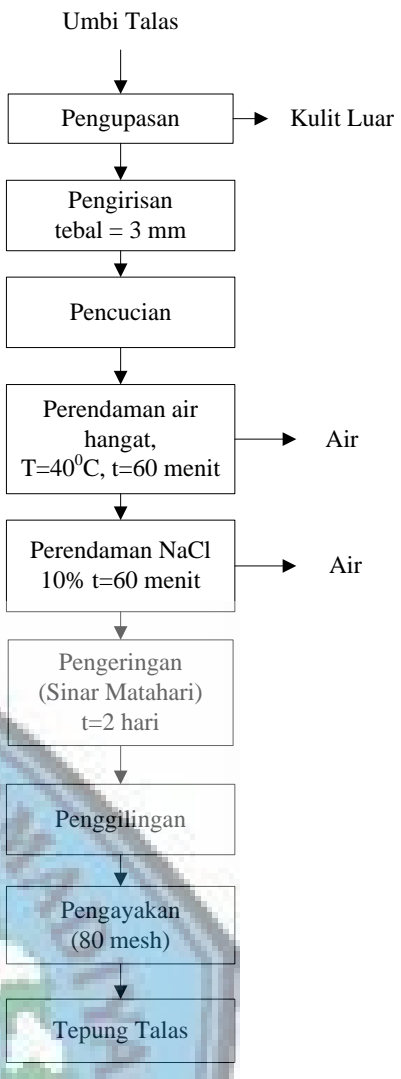

Gambar 1. Diagram Alir Penepungan Umbi Talas

\section{Pembuatan Pasta Bayam}

Pemastaan bayam diawali menseleksi sayur bayam. Selanjutnya dilakukan proses pembersihan dan dilanjutkan dengan proses blanching dengan suhu mencapai $100^{\circ} \mathrm{C}$ selama 10 menit. Bayam yang telah layu kemudian dihaluskan dengan menggunakan blander hingga tekstur bayam menyerupai pasta (Kuswardhani et al., 2003).

\section{Proses Pembuatan Flakes}

Proses pembuatan flakes ini mengacu pada penelitian Kuswardhani et al. (2003). 
Tahap pertama yaitu mencampurkan kedua bahan dasar yaitu tepung umbi talas dan pasta bayam. Ada tiga perlakuan yang didasarkan pada persentaseantara berat tepung umbi talas dengan pasta bayam yaitu 100\%:0\%; 90\%:10\%; 80\%:20\%; dan 70\%:30\%. Berat kedua bahan dasar tersebut dalam satu kali proses pembuatan flakes yaitu 200gr. Tahap yang kedua mencampurkan bahan pendukung lainnya yaitu: $25 \mathrm{~g}$ gula halus, 0,5 butir telur, $35 \mathrm{~g}$ margarin, $2 \mathrm{~g}$ garam, $25 \mathrm{~g}$ susu skim dan menambahkan air secukupnya hingga menjadi adonan. Tahap ketiga yaitu pengukusan adonan selama 10 menit dengan tujuan agar terjadi proses pre-gelatinisasi sehingga flakes tidak pecah. Tahap yang keempat yaitu proses pemipihan adonan dengan menggunakan alat roller hingga diperoleh lembaran flakes dengan ketebalan $\pm 1 \mathrm{~mm}$. Tahap berikutnya yaitu pencetakan flakes dengan ukuran $1 \times 2 \mathrm{~cm}^{2}$. Selanjutnya tahap yang terakhir yaitu pemanggangan potongan flakes dengan menggunakan oven lstrik pada suhu $120^{\circ} \mathrm{C}$ selama 20 menit.

\section{Analisis Kadar Zat Besi}

Pengukuran kadar zat Fe produk flakes menggunakan alat Spektrofotometer Serapan Atom (SSA). Metode ini sesuai yang dilakuakn oleh Herman et al. (2011) Tahapannya yaitu: Sampel dihomogenkan terlebih dahulu, kemudian dipipet sebanyak $50 \mathrm{ml}$. Sampel kemudian didestruksi, hasil destruksi kemudian di analisis dengan menggunakan alat Spektrofotometer Serapan Atom (SSA).

\section{Analisis Daya Terima}

Prosedur analisis daya terima dilakukan sesuai penelitian Istinganah, et al. (2017) yaitu dengan cara menguji sampel flakes dengan kombinasi bahan dasar tepung ubi talas dengan pasta bayam yaitu 100\%:0\%; 90\%:10\%; $\quad 80 \%: 20 \%$; dan $70 \%: 30 \%$. Pengujian dilakukan oleh panelis agak terlatih sebanyak 30 orang dengan penskoran terdiri dari 7 skala, yaitu:



Tahapan uji daya terima yaitu mula-mula panelis duduk di depan meja, kemudian masing-masing panelis diberikan 4 jenis produk flakes umbi talas dengan substitusi pasta bayam yang berbeda-beda. Sample produk flakes masing-masing diberikan kode 3 angka acak pada masing-masing sampel flakes. Panelis kemudian diberikan arahan untuk menilai secara sensoris dengan 
mengecap sampel flakes ke dalam mulut. Setelah panelis mengecap semua produk, selanjutnya panelis dimohon untuk mengisi form penilian yang telah disiapkan sebelumnya. Parameter yang dinilai pada uji daya terima meliputi aroma, rasa, tekstur, warna, dan keseluruhan.

\section{Rancangan Penelitian}

Penelitian ini menggunakan Rancangan Acak Lengkap. Penelitian dilakukan dengan 2 kali ulangan, dan ulangan analisis pada setiap sampel dilakukan sebanyak 3 kali. Sampel flakes yang diuji yaitu dari kombinasi bahan dasar antara tepung umbi talas dengan pasta bayam dengan persentase sebagai berikut: 100\%:0\%; 90\%:10\%; 80\%:20\%; dan 70\%:30\%. Hasil data kadar besi kemudian diuji dengan menggunakan analisis One Way Anova. Uji Kruskal Wallis digunakan untuk menganalisis data uji daya terima. Masingmasing data yang menunjukkan signifikansi pengaruh perlakuan akan dilanjutkan dengan Uji Duncan.

\section{HASIL DAN PEMBAHASAN}

\section{Analisis Kadar Zat Fe}

Analisis kadar Fe (besi) dilakukan pada masing-masing sampel flakes dengan persentase tepung talas dan bayam yang berbeda yaituSB1 (100:0) 100\% tepung talas
: 0\% bayam, SB2 (90:10) 90\% tepung talas : 10\% bayam, SB3 (80:20) 80\% tepung talas : $20 \%$ bayam, SB4 (70:30) $70 \%$ tepung talas : $30 \%$ bayam. Hasil analisis kadar zat besi pada masing-masing flakes disajikan pada Tabel 1.

Tabel 1. Jumlah Kadar Besi Pada Flakes

\begin{tabular}{cc}
\hline Sampel Flakes & Kadar Zat besi $(\mathrm{mg} / \mathrm{kg})$ \\
\hline SB1 $(100: 0)$ & $20.56 \pm 0.87^{\mathrm{a}}$ \\
SB2 $(90: 10)$ & $25.83 \pm 0.31^{\mathrm{b}}$ \\
SB3 $(80: 20)$ & $30.77 \pm 0.67^{\mathrm{c}}$ \\
SB3 $(70: 30)$ & $34.25 \pm 0.38^{\mathrm{d}}$ \\
\hline
\end{tabular}

Notasi huruf berbeda menunjukkan perbedaan yang nyata

Berdasarkan Tabel 1. diketahui bahwa kadar zat besi tertinggi (34.25 $\mathrm{mg} / \mathrm{kg})$ terdapat pada sample flakes SB3 (70:30) dimana sample flakes ini menggunakan persentase substitusi pasta bayam yang paling tinggi yaitu 30\%. Berdasarkan uji Duncan diketahui bahwa ada perbedaan nyata kadar Fe antara sampel flakes SB1, SB2, SB3, dan SB4 yang ditunjukkan dengan notasi huruf superscript yang berbeda pada Tabel 1. Hasil analisis menunjukkan bahwa semakin banyak konsentrasi bayam yang ditambahkan pada bahan flakes maka jumlah kadar Fe semakin meningkat. Kuswardhani (2003) menjelaskan bahwa kadar besi produk cookies terus menigkat seiring dengan 
bertambahnya jumlah konsentrasi bayam yang dicampurkan.

Pada flakes SB1 dengan tanpa penambahan bayam diketahui bahwa kadar besi mencapai 20,56mg/kg. Jumlah kadar besi tersebut dapat berasal dari bahan umbi talas maupun bahan pendukung lain seperti telur. Menurut Alcantara et al. (2013) bayam merupakan bahan pangan sumber mineral yang baik diantaranya yaitu besi dan seng.

\section{Analisis Daya Terima}

\section{Warna}

Analisis daya terima terhadap warna dilakukan pada masing-masing sampel flakes dengan persentase tepung talas dan bayam yang berbeda yaitu SB1 (100:0); SB2 (90:10); SB3 (80:20); dan SB4 (70:30). Hasil analisis daya terima warna pada masingmasing flakes disajikan pada Grafik 1.

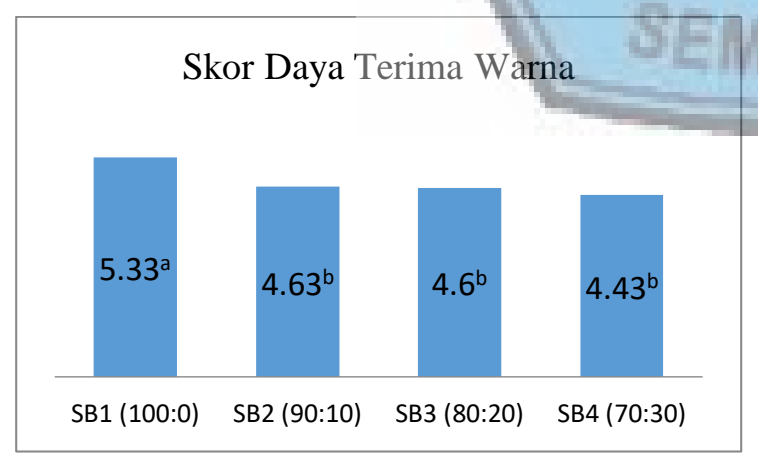

Notasi huruf berbeda menunjukkan perbedaan yang nyata

Grafik 1. Skor Daya Terima Terhadap Warna
Berdasarkan hasil uji statistik dengan menggunakan uji Kruskal-Wallis didapat nilai $\mathrm{p}=0.000$ ( $\mathrm{p}$ value $<0.05$ ), yang berarti bahwa ada pengaruh substitusi bayam pada penilaian panelis terhadap skor warna flakes ubi talas. Uji lanjutan dengan uji Duncan menunjukkan bahwa ada perbedaan nyata terhadap skor warna yang diberikan oleh panelis pada flakes ubi talas. Nilai daya terima warna flakes umbi talas dengan substitusi bayam 10\%, 20\%, 30\% berbeda nyata dengan flakes umbi talas dengan substitusi bayam $0 \%$.

Berdasarkan Grafik 1. diketahui bahwa rata-rata panelis memberikan penilaian "suka" terhadap flakes dengan tanpa penambahan bayam. Namun pada subtitusi bayam $10 \%, 20 \%$ dan $30 \%$ rata-rata panelis menilai "agak suka" terhadap warna flakes. Berdasarkan skor daya terima warna diketahui bahwa flakes SB1 lebih disukai oleh panelis bila dibandingkan dengan Flakes SB2, SB3, dan SB4. Hal ini dapat dikarenakan semakin tinggi persentase bayam yang ditambahkan akan membuat produk flakes semakin berwarna hijau gelap sehingga akan mempengaruhi daya terima terhadap warna flakes. Indraswari et al. (2017) mengatakan bahwa daya terima produk pangan dipengaruhi oleh jumlah 
konsentrasi bayam yang ditambahkan, semakin tinggi konsentrasi bayam akan terjadi penurunan daya terima warna.

\section{Aroma}

Analisis daya terima terhadap aroma dilakukan pada masing-masing sampel flakes dengan persentase tepung talas dan bayam yang berbeda yaitu SB1 (100:0); SB2 (90:10); SB3 (80:20); dan SB4 (70:30). Hasil analisis daya terima aroma pada masingmasing flakes disajikan pada Grafik 2.

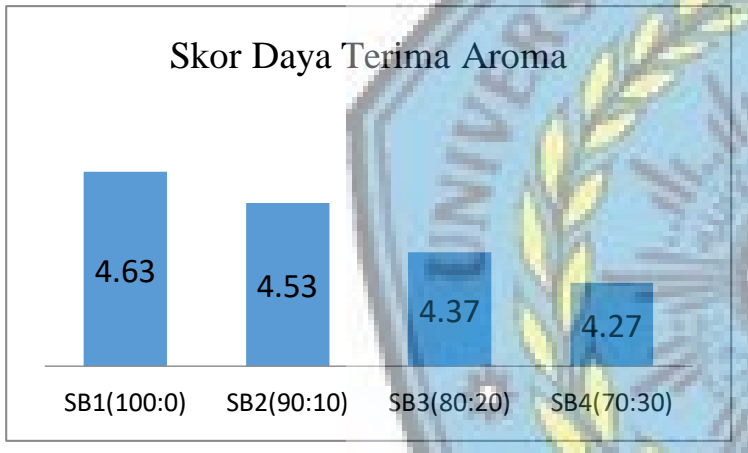

Grafik 2. Skor Daya Terima Terhadap Aroma

Berdasarkan hasil uji statistik dengan menggunakan uji Kruskal-Wallis didapat nilai $\mathrm{p}=0.343$ ( $\mathrm{p}$ value $<0.05$ ), yang berarti bahwa tidak ada pengaruh substitusi bayam pada penilaian panelis terhadap skor aroma flakes ubi talas. Uji statistic tidak dilanjutkan ke uji Duncan karena tidak ada pengaruh substitusi bayam terhadap skor aroma pada flakes umbi talas.
Berdasarkan Grafik 2. diketahui bahwa skor tertinggi daya terima terhadap aroma dari sampel flakes SB1 yaitu sebesar 4.63. Skor tersebut bermakna "agak suka". Berdasarkan nilai skor daya terima terhadap aroma diketahui bahwa semakin tinggi persentase bayam yang diberikan maka semakin menurun skor daya terima terhadap aroma flakes. Penerimaan terhadap aroma flakes dapat dipengaruhi oleh aroma langu yang ada pada produk flakes. Menurut Fitriyani (2013) penambahan konsentrasi bayam pada produk roti tawar bisa menimbulkan aroma langu sehingga akan mempengaruhi daya terima produk.

\section{Rasa}

Analisis daya terima terhadap rasa dilakukan pada masing-masing sampel flakes dengan persentase tepung talas dan bayam yang berbeda yaitu SB1 (100:0); SB2 (90:10); SB3 (80:20); dan SB4 (70:30). Hasil analisis daya terima rasa pada masing-masing flakes disajikan pada Grafik 3.

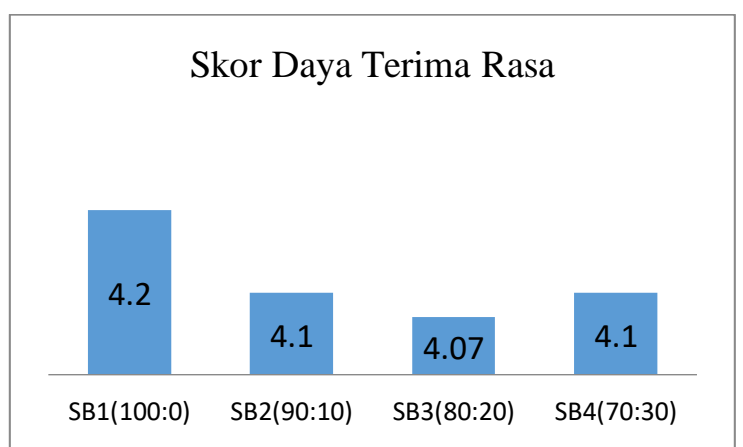


Grafik 3. Skor Daya Terima Terhadap Rasa

Berdasarkan hasil uji statistik dengan menggunakan uji Kruskal-Wallis didapat nilai $\mathrm{p}=0.950$ ( $\mathrm{p}$ value $<0.05)$, yang berarti bahwa tidak ada pengaruh substitusi bayam pada penilaian panelis terhadap skor rasa flakes ubi talas. Uji statistik tidak dilanjutkan ke uji Duncan karena tidak ada pengaruh substitusi bayam terhadap skor rasa pada flakes umbi talas.

Berdasarkan Grafik 3. diketahui bahwa skor rasa tingkat penerimaan panelis terhadap sampel flakes SB1, SB2, SB3, dan SB4 semua bermakna "agak suka”. Berdasarkan nilai skor daya terima terhadap rasa diketahui bahwa sampel SB1 mempunyai skor daya terima yang tertinggi. Hal ini berarti bahwa daya terima terhadap rasa flakes dengan prosentasi $0 \%$ bayam lebih diterima oleh panelis. Menurut Fitriyani (2013) rasa suatu produk pangan merupakan gabungan dari rasa komponen bahan penyusunnya.

\section{Tekstur}

Analisis daya terima terhadap tekstur dilakukan pada masing-masing sampel flakes dengan persentase tepung talas dan bayam yang berbeda yaitu SB1 (100:0); SB2 (90:10); SB3 (80:20); dan SB4 (70:30). Hasil analisis daya terima tekstur pada masingmasing flakes disajikan pada Grafik 4.

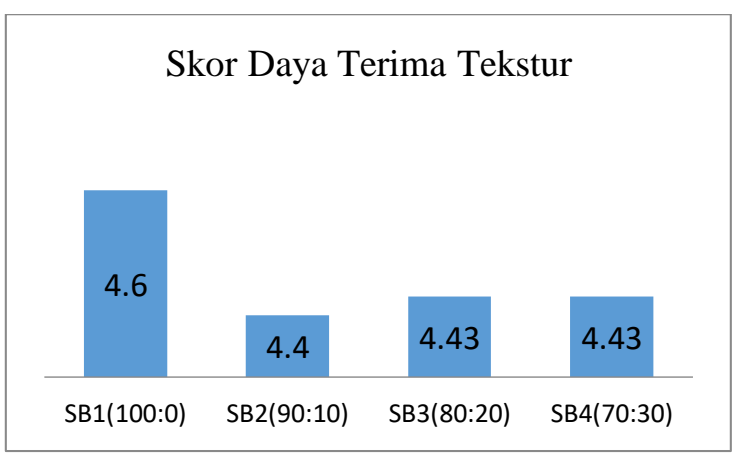

Grafik 4. Skor Daya Terima Terhadap Tekstur Berdasarkan hasil uji statistik dengan menggunakan uji Kruskal-Wallis didapat nilai $p=0.885(p$ value $<0.05)$, yang berarti bahwa tidak ada pengaruh substitusi bayam pada penilaian panelis terhadap skor tekstur flakes ubi talas. Uji statistik tidak dilanjutkan ke uji Duncan karena tidak ada pengaruh substitusi bayam terhadap skor tekstur pada flakes umbi talas.

Berdasarkan Grafik 4. diketahui bahwa panelis menilai "agak suka" terhadap sampel flakes SB1, SB2, SB3, dan SB4. Berdasarkan nilai skor daya terima terhadap tekstur diketahui bahwa sampel SB1 mempunyai skor daya terima terhadap tekstur yang tertinggi. Hal ini berarti bahwa flakes dengan tanpa penambahan bayam paling disukai oleh panelis. Menurut pendapat Setiaji (2008) tekstur flakes dipengaruhi oleh karakteristik 
pati yang ada pada bahan tepung yang digunakan.

\section{Keseluruhan}

Analisis daya terima keseluruhan dilakukan pada masing-masing sampel flakes dengan persentase tepung talas dan bayam yang berbeda yaitu SB1 (100:0); SB2 (90:10); SB3 (80:20); dan SB4 (70:30). Hasil analisis daya terima secara keseluruhan pada masing-masing flakes disajikan pada Grafik

5 .

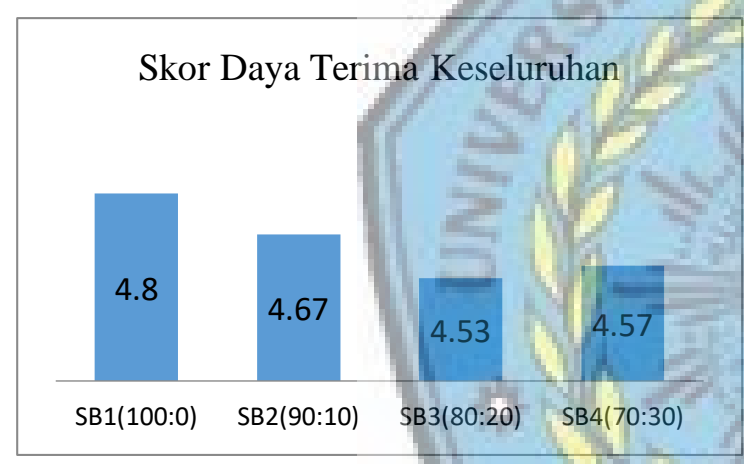

Grafik 5. Skor Daya Terima Keseluruhan

Berdasarkan hasil uji statistik dengan menggunakan uji Kruskal-Wallis didapat nilai $\mathrm{p}=0.950$ ( $\mathrm{p}$ value $<0.05)$, yang berarti bahwa tidak ada pengaruh substitusi bayam pada penilaian panelis terhadap skor daya terima keseluruhan flakes ubi talas. Uji statistik tidak dilanjutkan ke uji Duncan karena tidak ada pengaruh substitusi bayam terhadap skor daya terima keseluruhan pada flakes umbi talas.
Berdasarkan nilai skor daya terima keseluruhan diketahui bahwa sampel SB1 mempunyai rata-rata skor daya terima keseluruhan paling tinggi (4.8). Hal ini berarti bahwa secara keseluruhan yang paling disukai oleh panelis yaitu flakes dengan tanpa kombinasi bayam. Menurut Indraswari et al. (2017) semakin meningkatnya jumlah penambahan bayam pada produk nugget maka terjadi penurunan daya terima secara keseluruhan.

\section{KESIMPULAN DAN SARAN}

\section{KESIMPULAN}

Hasil penelitian yang telah diperoleh dapat disimpulkan bahwa substitusi bayam pada flakes umbi talas berpengaruh secara signifikan terhadap kadar Fe dan skor warna yang diberikan oleh panelis terhadap flakes umbi talas. Substitusi bayam pada flakes umbi talas tidak berpengaruh terhadap skor tekstur, aroma, rasa, dan keseluruhan flakes umbi talas.

\section{SARAN}

Saran yang perlu disampaikan yaitu perlu ada penelitian lanjutan untuk mengetahui analisis zat gizi lain selain $\mathrm{Fe}$ dalam produk flakes umbi talas dengan penambahan bayam. 


\section{DAFTAR PUSTAKA}

Abbaspour, N., Hurrell, R., \& Kelishadi, R. (2014). Review on iron and its importance for human health. Journal of research in medical sciences : the official Journal of Isfahan University of Medical Sciences, 19(2), 164-174.

Achigan-Dako, E. G., Sogbohossou, O. E. D. Maundu, P. 2014. Current knowledge on Amaranthus spp.: research avenuesfor improved nutritional value and yield in leafyamaranths in sub-Saharan Africa. Springer Science+Business Media Dordrecht 2014

Alcantara, R. M., Hurtada, W. A., Dizon, E. I. 2013. The Nutritional Value and Phytochemical Components of Taro [Colocasia esculenta (L.) Schott] Powder and its Selected Processed Foods. J Nutr $\begin{array}{llll}\text { Food } & \text { Sci } & 2013, & 3: 3 .\end{array}$ https://www.longdom.org/open-access

Aminah, S. 2016. Fortifikasi Bayam Terhadap Biskuit. Balai Pengkajian Teknologi Pertanian (BPTP) Jakarta

Chaïr, H., Traore, R. E., Duval, M. F.,Rivallan, R., Mukherjee, A., Aboagye4L. M.,Van Rensburg, W.J., Andrianavalona, V.,Pinheiro de Carvalho, M. A. A., Saborio, F., Pana, S., Komolong, B.,Lawac, F., Lebo, V. 2016. Genetic Diversification and Dispersal of Taro(Colocasiaesculenta(L.) Schott). Journal Plos One: 2016. https://journals.plos.org/plosone/article/fil e?id=10.1371

Fitriany, J. Saputri, A. I. 2018. Anemia Defisiensi Besi. Jurnal Averrous Vol.4 No.2: 2018

Fitriyani. 2013. Eksperimen Pembuatan Roti Tawar Dengan Penggunaan Sari Bayam (Amaranthus Sp).Fscej 2 (2). UNNES. Semarang.
Herman., Rusli, R., Ilimu, Edi., Hamid, R., Haeruddin. 2011. Analisis Kadar Mineral dalam Abu Buah Nipa (Nypa fructicans) Kaliwanggu Teluk Kendari Sulawesi Tenggara. J. Trop. Pharm. Chem. Vol 1. No. 2. Hal: 104-110

Indraswari, D., Farida, W.N., dan Rohmawati, N. 2017. Pengaruh Penambahan Bayam Pada Nugget Kaki Naga Lele (Clarias Garinipus) Terhadap Kadar Zat Besi, Protein, Dan Air. Penelitian Gizi Dan Makanan. Vol. 40(1): 9-16.

Istinganah, M., Rauf, R., Widyaningsih, E. N. 2017. Tingkat Kekerasan dan Daya Terima Biskuit Dari Campuran Tepung Jagung dan Tepung Terigu Dengan Volume Air Yang Proporsional. Jurnal Kesehatan, Universitas Muhammadiyah Surakarta, Vol. 10, No. 2, Desember 2017, Hal: 83-93

Košutić, M. Filipović, J. Pezo, L. Plavšić, D. Ivkov, M. 2016. Physical and sensory properties of corn flakes with added dry residue from wild oregano distillation. JournalSerbian Chemical Society. 81 (9) 1013-1024 (2016).

Kuswardhani, D.S., Yaniasih., dan Pranadi, B. 2003. Fortifikasi Fe Organik Dari Bayam (Amaranthus Tricolor L) Dalam Pembuatan Cookies Untuk Wanita Mesntruasi. PKMI-1-03-1.IPB. Bogor.

Neulicht, R., Shular, J. 1995. Cereal Breakfast Food. Emission Factor Documentation for AP-42. Section 9.9.2. Final Report. U. S. Environmental Protection Agency.

Paramita A.H, Putri W.D.R. 2015. Pengaruh Penambahan Tepung Bengkuang Dan Lama Pengukusan Terhadap Karakteristik Fisik, Kimia, Dan Organoleptik Flakes Talas. Jurnal Pangan Dan Agroindustri Vol. 3 No 3 P.1071-1082 
Prana, M.S. 2007. Studi Biologi Pembungaan pada Talas (Colocasia esculenta (L.) Schott.). Biodiversitas Vol (8) No. 1: 6366 (2007) http://biodiversitas.mipa.uns.ac.id/D/D08 01/D080113.pdf

Schwartz, M. B., Vartanian, L.R., Wharton, C. M., Brownell, K. D. 2008. Examining the Nutritional Quality of Breakfast Cereals Marketed to Children. Journal Of The American Dietetic Association. Vol. 108 No. 4. Page: 702-705

Setiaji, B. 2008. Pengaruh Suhu Dan Lama Pemanggangan Terhadap Karakteristik Soyflakes (Glycine Max L). Artikel. Universitas Pasundan. Bandung.

Srivastava, R. 2011. Nutritional Quality Of Some Cultivated And Wild Species Of
Amaranthus L. International Journal of Pharmaceutical Science and Research. Vol: 2 No. 12: 3152-3156

Sudomo, A., Hani, A. 2014. Produktivitas Talas (Colocasia esculenta (L.) Schott) di Bawah Tiga Jenis Tegakan dengan Sistem Agrofoerstri di Lahan Hutan Rakyat. Jurnal Ilmu Kesehatan Vol: 8 No. 2: 2014

Sukasih, E., Setyadjit. 2012. Formulasipembuatan flakes berbasistalasuntukmakanansarapan (breakfast meal) energy tinggi dengan metode oven. Journal Pascapanen 9(2) 2012: 70-76 .

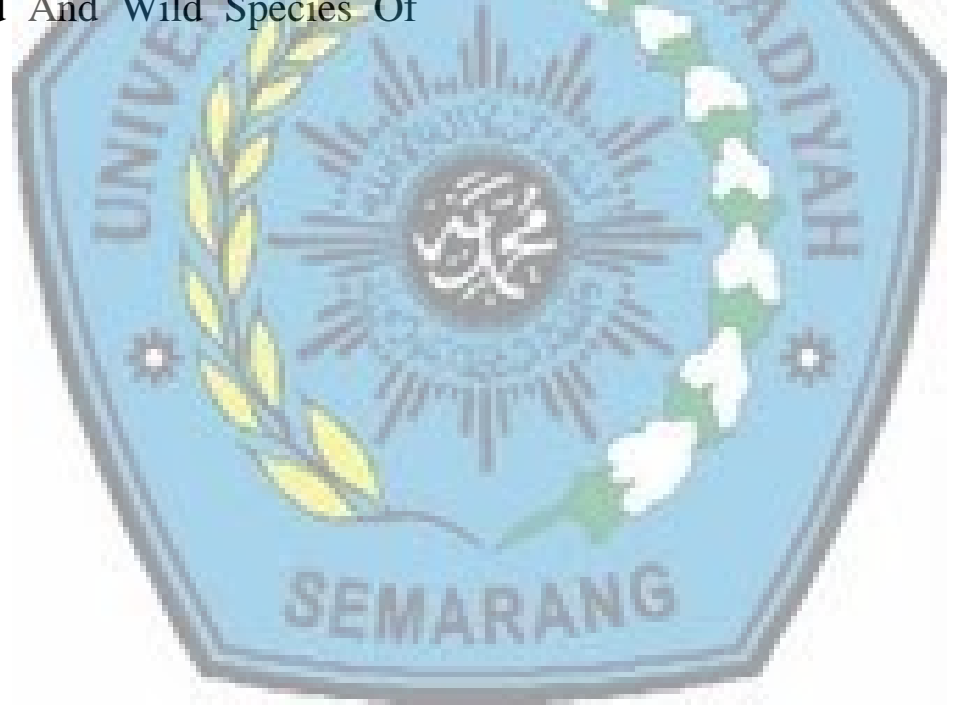

